\title{
Hand-Raise Detection Pada Kelas Cendekia Menggunakan Kamera RGB dan Depth
}

\author{
Muhammad Fajar Khairul Auni *1, Muhammad Idham Ananta Timur ${ }^{2}$, Ika Candradewi ${ }^{3}$ \\ ${ }^{1}$ Prodi Elektronika dan Instrumentasi, DIKE, FMIPA, UGM, Yogyakarta, Indonesia \\ ${ }^{2}$ Departemen Ilmu Komputer dan Elektronika, FMIPA, UGM, Yogyakarta, Indonesia \\ e-mail: *21 fajar.glt@gmail.com, ${ }^{2}$ idham@ugm.ac.id, ${ }^{2}$ ika.candradewi@ugm.ac.id
}

\begin{abstract}
Abstrak
Kebutuhan kelas cendekia untuk melakukan penentuan angkat tangan tercepat pembicara yang terdapat pada ruangan kelas dengan menggunakan konsep ubiquitous computing dimana teknologinya ada akan tetapi tidak terasa disekitarnya. Konsep kelas tersebut membutuhkan beberapa kemampuan diantaranya mengetahui jarak ideal dari kamera, melakukan deteksi gerakan angkat tangan dari pembicara secara real-time menggunakan metode AdaBoost, dan melakukan penentuan angkat tangan tercepat dari pembicara secara real-time. Jarak ideal kamera terhadap pembicara sekitar $250 \mathrm{~cm}$. sistem memiliki akurasi deteksi menggunakan metode AdaBoost sebesar 97.485497 \% dan akurasi menggunakan koordinat titik sendi sebesar 98\%. Sistem juga mampu menentukan waktu tercepat menggunakan metode AdaBoost dengan akurasi 93.5\% dan akurasi angkat tangan tercepat menggunakan koordinat titik sendi sebesar $95 \%$.
\end{abstract}

Kata kunci-Ubiquitous computing, kelas cendekia, Kinect, Gesture Recognition, AdaBoost

\begin{abstract}
The requisite of intelligent classroom's to perform the quickest speaker lift determination of speakers in the classroom using the concept of ubiquitous computing where the technology exists but does not feel around. The classroom concept requires several capabilities such as knowing the ideal distance from the camera, performing real-time hand-lifted movements from the speaker using the AdaBoost method, and determining the fastest hand lift from the speaker in real-time. The camera's ideal distance to speakers is about $250 \mathrm{~cm}$. the system has a detection accuracy of $97.485497 \%$ and accuracy using coordinates joint point of 98\%. The system is also capable of determining the fastest time using AdaBoost with $93.5 \%$ accuracy and the accuracy of the fastest hands lifting using coordinates joint point of $95 \%$.
\end{abstract}

Keywords-Ubiquitous Computing, intelligent classroom, Kinect, Gesture Recognition, AdaBoost 


\section{PENDAHULUAN}

Konsep kelas cendekia adalah memanfaatkan komputer tetapi komputer tersebut tidak tampak keberadaannya secara visual yang disebut dengan disappearing computer. Konsep ini dijelaskan oleh mark weiser, yaitu sebuah teknologi yang canggih adalah ketika teknologi itu sendiri tidak tampak keberadaannya secara visual tetapi teknologi itu melebur kedalam kehidupan sehari-hari manusia hingga tidak dapat dirasakan kehadirannya [1] Konsep ini merupakan gagasan masa depan dimana pada ruang diskusi dalam hal penyampaian pendapat dapat di tentukan secara efektif dan tepat dengan bantuan komputer tetapi keberadaan komputer tersebut tidak dapat terlihat secara visual. Dari konsep Mark Weiser tersebut dikembangkan sebuah kelas yang memanfaatkan konsep ubiquitous computing dengan menggunakan komputer sebagai fasilitas dalam berdiskusi dan memiliki kemampuan menentukan angkat tangan tercepat. Ide besar yang diharapkan dari kelas cendekia adalah para peserta diskusi dapat kembali pada fitrahnya. Saat diskusi berlangsung, pesrta dapat memberikan pendapat secara aktif mengenai suatu issue yang dibahas dengan mengangkat tangannya sebelum menyampaikan informasinya.

Kelas cendekia adalah suatu kelas yang menyediakan suatu fasilitas dalam bentuk ruangan untuk berdiskusi. Kegiatan dikelas cerdas [2] ini layaknya kelas diskusi pada umumnya yaitu melakukan suatu tanya-jawab yang memberikan informasi berharga bagi pihak lain. Oleh sebab itu dilakukan penelitian yang mampu menentukan angkat tangan tercepat pembicara pada ruangan diskusi. Gerakan tersebut hanya melihat tubuh bagian atas saja untuk dilakukan pengenalan gerakan pada Kinect.

Pada dasarnya orang yang terlibat dalam ruangan diskusi tidak banyak campur tangan dalam menentukan angkat tangan tercepat. Pada kelas cendekia ini orang yang terdapat pada ruangan hanya duduk saja dan mengangkat tangannya dan sistem yang akan mendeteksi gerakan tersebut dan mengetahui siapa yang tercepat. Penentuan angkat tangan tercepat menggunakan sensor Kinect. Sensor Kinect memiliki sebuah kamera RGB, sensor kedalaman dan multi-array michrophone yang dilengkapi software development kit [3].

Kinect tersebut yang menjadi sensor dalam sistem untuk menentukan gerakan angkat tangan pembicara. Kinect merupakan sensor gerak yangb biasa digunakan dalam konsol game Xbox yang bersifat real-time dan alami [4]. Pendeteksian gerakan angkat tangan ini melihat gerakan pada tubuh bagian atas dan menampilkan hasilnya secara real-time.

Pendeteksian gerakan ini mempermudah dalam proses diskusi pada kelas cendekia. Hal ini dapat mempercepat proses dan menjadikan teknologi dapat berperan dalam ruangan diskusi. Pendeteksian gerakan tersebut memiliki dua metode yaitu dengan database dari tools Kinect SDK dan koordinat titik sendi dari pembicara. Pada database yang bersifat diskrit yang hanya menerima inputan benar dan salah dalam bentuk biner [5].

Deteksi gerakan pada penelitian ini memanfaatkan pengenalan gerakan untuk setiap pembicara. Penggunaan Kinect sebagai sensor masukan dari sistem untuk mengenali gerakan angkat tangan pembicara dan di ibaratkan menjadi indera kemampuan computer. Salah satu usaha pengembangan interaksi manusia dengan komputer yaitu dengan memberikan komputer indera kemampuan untuk menerima sesuatu dan memberikan respon/tanggapan, dalam hal ini indera untuk melihat atau melacak pergerakan suatu objek[6]. Kemampuan ini dilakukan untuk mendeteksi gerakangan angkat tangan pembicara pada ruangan diskusi.

\section{METODE PENELITIAN}

Sistem deteksi yang digunakan pada penelitian ini merupakan deteksi gerakan angkat tangan. Deteksi angkat tangan tersebut menggunakan databse AdaBoost dan metode koordinat titik sendi pembicara. Jarak Antara kamera dengan user telah ditentukan melalui pengujian sistem dan ketahui sebesar $250 \mathrm{~cm}$. pada deteksi menggunakan AdaBoost sistem deteksi

IJEIS Vol. 8, No. 1, April 2018: $95-106$ 
memanfaatkan tools yang ada pada Kinect SDK. Pada deteksi menggunakan titik korrdinat titik sendi memanfaatkan kamera depth yang dapat mengetahui jarak objek dalam satuan meter [7]. Pada Gambar 1 menunjukan visualisasi letak kamera terhadap pembicara.

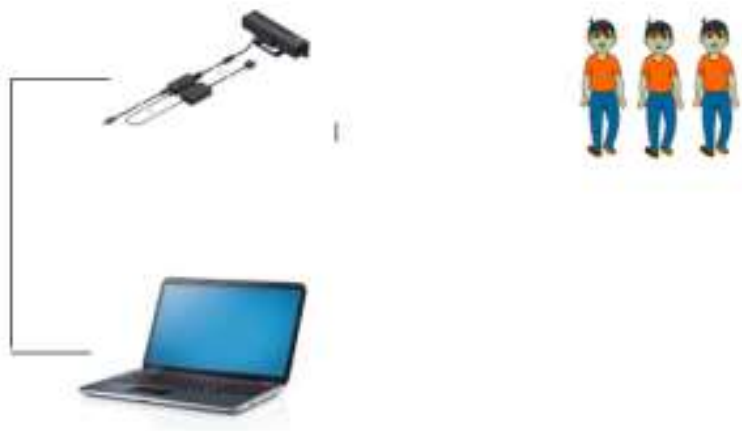

Gambar 1 Visualisasi letak kamera terhadap pembicara

\subsection{Deskripsi Sistem}

Diagram blok pada Gambar 2 merupakan penjelasan cara kerja sistem deteksi dan penentuan angkat tangan tercepat dalam kelas dcendekia. Berawal dari masukan informasi berupa citra yang didapatkan dari sensor kinect mendeteksi gerakan angkat tangan dan waktu tercepat pembicara.

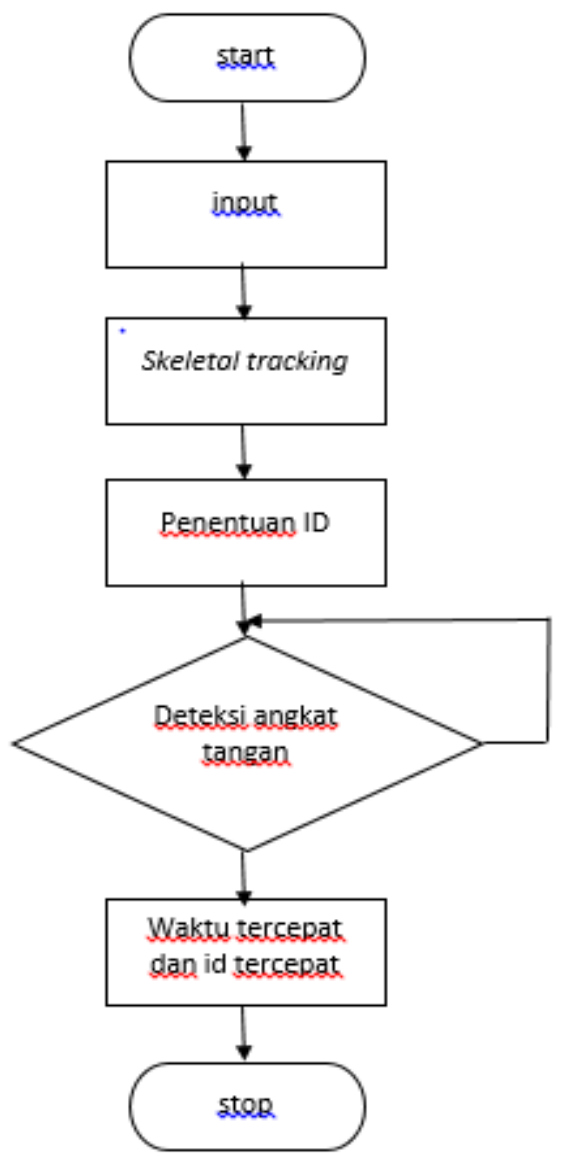

Gambar 2 Diagram Alir Sistem 
Kegiatan pertama adalah mengambil video secara real-time menggunakan sensor Kinect. Video tersebut mengandung gerakan pembicara pada ruangan diskusi. Setelah terdapat pembicara pada ruangan, sensor akan menghitung jumlah orang yang telah masuk ke dalam frame.penghitungan ini untuk mengetahui jumlah orang pada ruangan diskusi.

Kegiatan penghitungan jumlah orang tersebut dilakukan, maka tahap selanjutnya adalah melakukan tracking skeletal dari pembicara. Sesnsor Kinect mampu melakukan tracking titik sendi dari pembicara dan menentukan koordinat dalam satuan meter. Tracking skeletal ini dilakukan untuk memperoleh data titik sendi dari pembicara. Pada penelitian ini mendapatkan 25 titik sendi yang datap dilakukan tracking oleh Kinect.

Berdasarkan hasil tracking tersebut maka dilakukanlan pemberian ID untuk masingmasing pembicara yang terdapat pada ruangan. Pemberian ID ini dilakukan untuk menggambar kerangka digital untuk setiap pembicara pada ruangan. Penggambaran kerangka ini dapat dilakukan karena titik sendi dari masing-masing pembicara sudah diketahui pada saat proses skeletal tracking. Pada sstem akan menampilkan kerangka digital secara real-time untuk masing-masing pembicara.

Berdasarkan data kerangka digital tersebut dilakukanlah pendeteksian gerakan angkat tangan. Deteksi gerakan angkat tangan ini dilakukan dengan dua cara yaitu menggunakan database AdaBoost dan menggunakan koordinat titik sendi. Dari proses deteksi tersebut jika sistem mendeteksi gerakan angkat tangan, maka sistem akan menyimpan nilai waktu dan ID pembicara yang terdeteksi angkat tangan. Hasil tersebut akan dibandingkan nilai waktunya dan ditemukan waktu tercepat angkat tangan beserta ID tercepat angkat tangan.

\section{2 Sensor Kinect}

Kinect adalah suatu teknologi yang membuat user dapat berinteraksi secara natural dengan computer tanpa menggunakan controller. Dengan kata lain user, dapat melakukan suatu pengoperasian menggunakan gerakan tangan atau gerakan tubun lainnya [8]. Kinect dikembangkan oleh Microssoft untuk game conlose Xbox. Kinect berperan sebagai controller pada Xbox untuk mendeteksi gerakan user dan mencocokan dengan game. Konsep ini seperti yang terdapat pada Virtual Reality(VR). Kinect ditemukan pada tahun 2005 oleh Zeev Zalevsky, Alexander Shpunt, Aviad Maizels dan Javier Garcia[9].

Kinect memiliki beberapa fitur meliputi kamera RGB, depth sensor, dan multi array microphone. Pada gambar 3 menunjukan sensor Kinect.

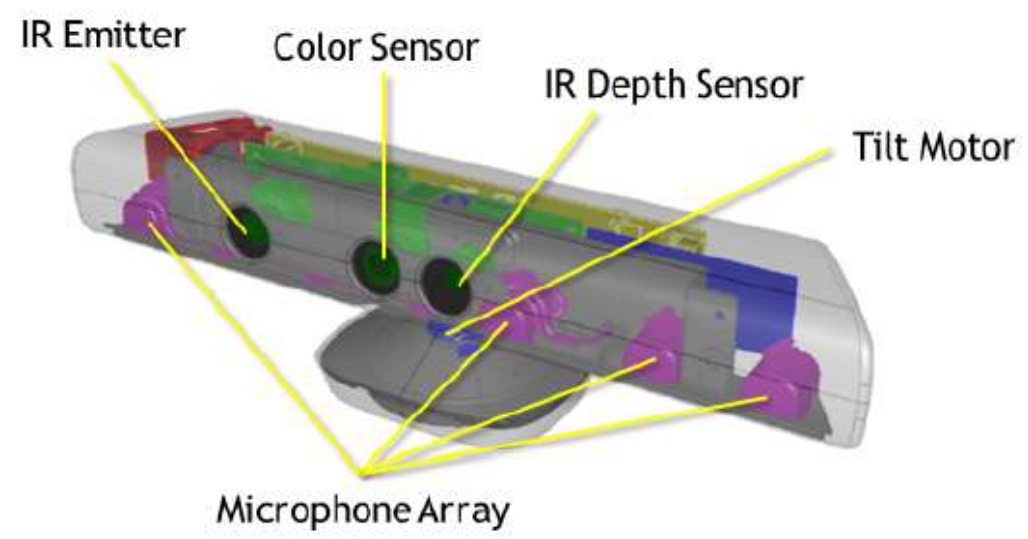

Gambar 3 Sensor Kinect [8] 
Sensor Kinect memiliki fitur kamera RGB. Kamera RGB pada Kinect ini mampu streaming video menggunakan resolusi VGA $(640$ x 480 piksel $)$ dengan bayer filter warna (Sunarso et al., 2017). Kamera RGB pada Kinect ini berfungsi untuk menangkap/merekam video untuk kepentingan penagkapan gerakan user. Kamera ini berfungsi layaknya kamera webcam pada umumnya, sehingga Kinect dapat merekam seluruh video ataupun mengcapture citra per frame.

Sensor Kinect juga memiliki fitur depth sensor atau sensor kedalaman. Depth sensor ini terdiri dari kombinasi infrared laser projector dan monochrome CMOS sensor yang mengambil data video dalam 3D tanpa memperdulikan kondisi cahaya . Cara kerja dari Depth sensor ini adalah Kinect memancarkan infrared yang tidak dapat dilihat kasat mata dan tidak berbahaya bagi tubuh manusia [10]. Infrared itu mengirimkan ribuan sinar yang memantul untuk mengetahui posisi objek yang terdapat di depannya. Sinar infrared yang dipantulkan tersebut akan ditangkap oleh kamera monochrome CMOS sensor untuk mengukur waktu sinar yang didapat setelah terpantul oleh objek yang ada di depannya. Nilai inilah yang akan digunakan untuk memetakan objek secara 3D dan mengetahui posisi dari objek tersebut.

Skeletal tracking ini adalah sebuah fitur yang telah disediakan oleh Kinect SDK. Pada Kinect SDk terdapat skeletal traking yang berfungsi untuk melacak posisi titik sendi utama pada tubuh manusia. Hasil ini didapatkan dari cara kerja depth sensor. Depth sensor memetakan objek berdasarkan jarak yang akan dibandingkan dengan data hasil tracking sebelumnya sehingga didapatkan data skeletal tracking dari manusia tersebut. Skeleton data ini dapan dihitung berdasarkan sudut antara dua sendi dari skeleton. Kinect akan melakukan skeletal tracking secara realtime. Skeletal tracking ini memungkinkan Kinect dapat mengenali user dan mengikuti pergerakannya. Kinect dapat mengenali user sampai dengan enam user, tetapi dari jumlah tersebut Kinect hanya dapat mengenali 2 user hingga detail.

Kinect SDK menyediakan suatu library untuk memudahkan mengakses seluruh titik sendi dari user. Pada Kinect SDK ini akan diketahui 20 titik sendi dari manusia. Setiap titik control didefinisikan oleh posisi $(\mathrm{X}, \mathrm{Y}, \mathrm{Z})$ yang dinyatakan dalam skeleton space. Skeleton space didefinisikan di sekitar sensor yang terletak di titik $(0,0,0)$ dimana sumbu $\mathrm{X}, \mathrm{Y}$, dan $\mathrm{Z}$ bertemu [9] Pada gambar 4 menunjukan skeleton data user pada Kinect.

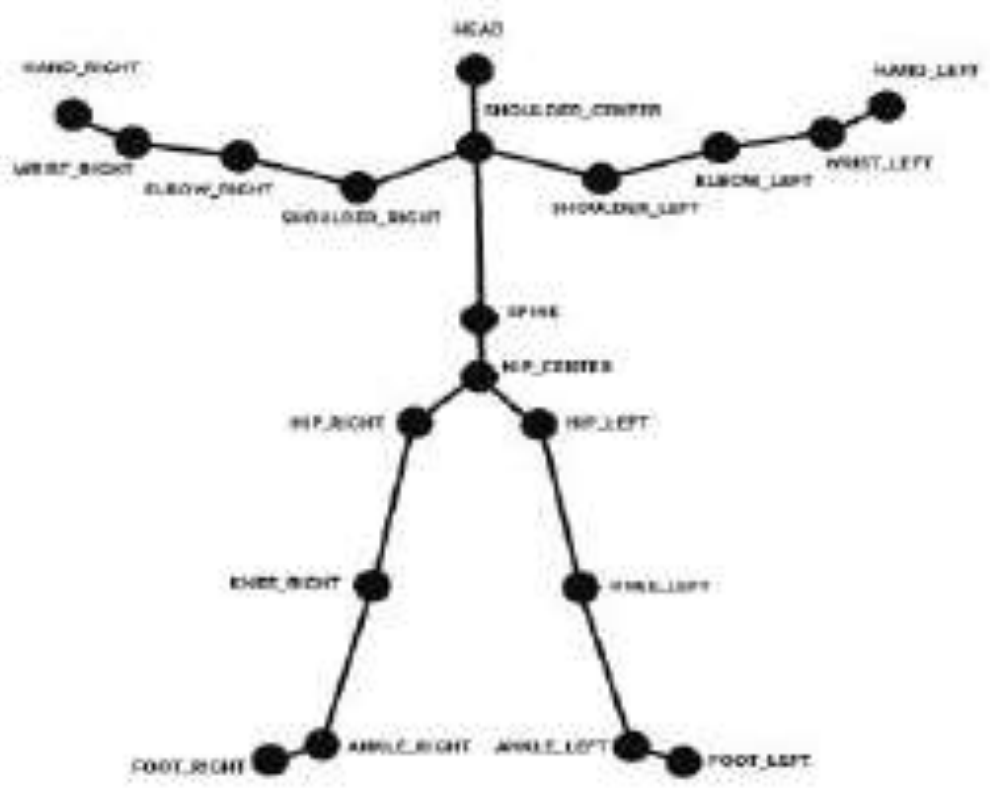

Gambar 4 Skeleton User [9] 


\subsection{Algoritma Penentuan Angkat Tangan Tercepat}

Penentuan angkat tangan tercepat didapatkann dari waktu deteksi angkat tangan pada masing-masing pembicara. Hasil waktu tersebut dibandingkan dan di dapatkan nilai waktu paling minimum. Waktu minimum ini yang menjadi waktu tercepat dan dari waktu minimum tersebut dapat diketahui ID pembicara yang paling cepat melakukan angkat tangan. Hasil dari proses penentuan angkat tangan tercepat disimpan dalam sebah file berbentuk ".csv". Pada Gambar 5 menunjukan diagram alir penentuan angkat tangan tercepat.

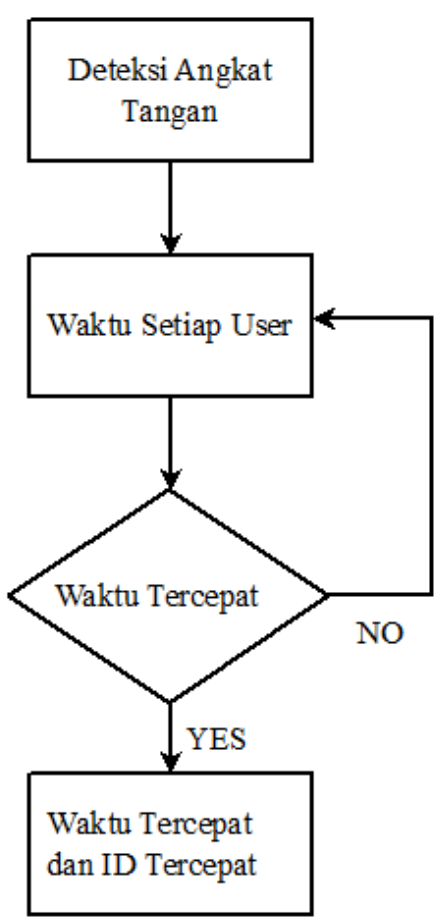

Gambar 5 Diagram Alir Penentuan Angkat Taangan Tercepat

\subsection{Metode AdaBoost}

Algoritma Adaboost adalah algoritma yang berusaha membangun strong classifier dengan mengkombinasikan sejumlah simple atau weak classifier secara linier. Algoritma ini menggunbakan prinsip dari pohon keputusan (decision trees), pohon keputusan yang digunakan bias berupa satu tingkatan cabang (decision stump) atau beberapa tingkatan cabang (dapat mencapai tiga tingkatan)[11]. Algoritma AdaBoost akan menghasilkan suatu keputusan dari weak learner. Perhitungan algoritma AdaBoost ini di tunjukan pada persamaan (1)

$$
\begin{aligned}
& F(x)=\sum_{t=1}^{T} \alpha_{t} h_{t}(x) \\
& h_{t}(x)=\text { weak atau basic classifier } \\
& \alpha_{t}=\text { tingkat pembelajaran (learning rate) } \\
& \mathrm{F}(\mathrm{x})=\text { final classifier }
\end{aligned}
$$

Algoritma ini menerima input berupa pembelajaran lemah (WeakLearn). Sebuah interger $\mathrm{t}$ yang menspesifikasi banyaknya iterasi dan data pelatihan sebanyak $\mathrm{N}$ $\left\{\left(x_{1}, y_{1}\right), \ldots,\left(x_{N}, y_{N}\right)\right\}$. Setelah itu akan dilakuan inisialisasi bobot pada setiap element dalam fitur vector. Inisialisasi bobot ini dirumuskan dengan $D_{1}(i)=1 /(n)$, dimana $n$ adalah jumlah 
element dalam fitur vector. Perhitungan ini juga menggunakan penentuan jumlah iterasi. Training dari weak classifier $h_{t}$, mengggunakan bobot dari $D_{1}$ sehingga dihasilkan $h_{t} \in\{-1,+1\}$.

Hasil tersebut akan dilihat error dari perhitungannya. Untuk menghitung kesalahan perhitungan weak classifier tterkait dengan jumlah bobot yang salah di klasifikasi dituliskan dengan persamaan(2)

$$
\text { error }_{t}=\sum_{i=0}^{m} D_{i}(i) h_{t}\left(x_{i}\right) y_{i} .
$$

Hasil dari perhitungan ini akan dilakukan perhitungan nilai alpha( $\alpha$ ). Nilai ini adalah bobot yang diterapkan pada masing-masing classifier seperti yang di tentukan oleh algoritma AdaBoost, sehingga akan didapatkan hasil akhir yaitu strong classifier dari algoritma AdaBoost seperti pada persamaan(1). Perhitungan nilai alpha ini akan ditunjukan pada persamaan(3).

$$
\alpha_{\mathrm{t}}=\log \left(\frac{1-\varepsilon_{\mathrm{t}}}{\epsilon_{\mathrm{t}}}\right)
$$

Dengan cara ini, akan menggabungkan output dari weak learner dan menciptakan strong learner yang pada akhirnya meningkatkan kekuatan model prediksi. Algoritma AdaBoost ini memiliki beberapa kelebihan yaitu :

1. AdaBoost mampu mengurangi nilai bias maupun perbedaan pada weak classifier.

2. AdaBoost memiliki kemampuan generalisasi yang baik.

3. Output AdaBoost mengkonversi ke logaritma rasio terdekat.

4. AdaBoost dapat dilihat sebagai pemilih fitur dengan strategi berprinsip (minimalisasi dari batas atas error).

5. AdaBoost dekat dengan pembuatan keputusan linier.

\section{5 metode koordinat titik sendi}

Pada metode ini dilakukan untuk mendeteksi gerakan angkat tangan pembicara pada ruangan diskusi. Kinect mampu melakukan tracking titik sendi dan mengetahui koordinat titik sendi dari pembicara pada ruangan diskusi. Kemampuan Kinect tersebut karena terdapat depth kamera yang memungkinkan Kinect mendeteksi jarak objek yang terdapat pada frame. Penentuan jarak tersebut dilakukan Kinect dalam satuan meter.

Penentuan gerakan seseorang dengan menggunakan Kinect dapat dilakukan dengan melihat koordinat titik sendi yang menjadi acuan untuk gerakan tersebut. Seseorang dikatakan melakukan gerakan ketika telah memenuhi kondisi(threshold) pada titik sendi yang menjadi acuan[12]. Pada penelitian ini yang menjadi acuan adalah koordinat dari pergelangan tangan kanan, pergelangan tangan kiri, dan kepala.

Pemanfaatan kemampuan Kinect ini digunakan untuk mendeteksi gerakan angkat tangan. Pada dasarnya, gerakan angkat tangan adalah gerangkan mengangkat tangan pembicara dan melewati posisi dari kepala pembicara tersebut. Untuk mengenali gerakan angkat tangan ini, maka sditentukan titik sendi yang menjadi acuan gerakan tersebut dikatakan oleh sistem sebagai gerakan angkat tangan. Dalam hal ini sendi yang menjadi acuan adalah pergelangan tangan kiri, pergelangan tangan kanan, dan kepala.

Pembacaan koordinat yang dapat dilakukan oleh Kinect berupa 3D (3 dimensi) meliputi sumbu X, Y, dan Z. Gerakan angkat tangan merukapan perbedaan posisi koordinat titik sendi dalam sumbu Y. Perbedaan posisi koordinat ini yang akan menjadi acuan untuk deteksi gerakan angkat tangan. Berdsarkan hal tersebut dapat dirumuskan deteksi angkat tangan menggunakan metode koordinat titik sendi ditunjukan pada persamaan (4).

$W_{R} Y>$ HeadY atau $W_{L} Y>$ Head $Y$

$\mathrm{W}_{\mathrm{R}} \mathrm{Y}=$ koordinat sumbu $\mathrm{Y}$ pergelangan tangan kanan

$\mathrm{W}_{\mathrm{L}} \mathrm{Y}=$ koordinat sumbu $\mathrm{Y}$ pergelangan tangan kiri

HeadY $=$ koordinat sumbu $Y$ kepala 


\section{HASIL DAN PEMBAHASAN}

Dari hasil implementasi dilakukan pengujian yang dilakukan untuk mendapatkan kehandalan sistem untuk mendeteksi gerakan angkat tangan dan penentuan angkat tangan tercepat. Sebelum pengujian tersebut dilakukan, Kinect mempunyai jarak ideal terhadap pembicara. Dilakukanlah pengujian untuk jarak ideal kamera terhadap pembicara.

Pada pengujian jarak ideal kamera dilakukan untuk mengetahui jarak ideal kamera terhadap pembicara dalam melakukan deteksi dan penggambaran kerangka digital masingmasing pembicara. Cara mencari jarak ideal kamera dengan memberikan variasi jarak kamera terhadap pembicara. Variasi jarak ini dilakukan dari rentang 50-450 cm.

Pengujian ini digunakan untuk melihat jarak ideal karena pada kamera tersebut akan merepresentasikan titik sendi dari pembicara yang nantinya akan di gambarkan kerangka digital dari masing-masing pembicara. Titik sendi yang di representasikan oleh kamera idealnya sebanyak 25 titik sendi. Titik sendi ini didapat menggunakan kamera depth yang dengan melihat jarak pembicara tersebut. Pada Tabel 1 menunjukan hasil pengujian jarak ideal kamera tehadap pembicara.

Tabel 1 pengujian jarak ideal kamera terhadap pembicara

\begin{tabular}{|l|l|l|l|}
\hline \multirow{2}{*}{$\begin{array}{l}\text { Jarak } \\
(\mathrm{cm})\end{array}$} & \multicolumn{2}{|c|}{ Gesture } & \multirow{2}{*}{$\begin{array}{c}\text { Jumlah sendi } \\
\text { error }\end{array}$} \\
\cline { 2 - 4 } & $\sqrt{ } 0$ & $\mathrm{X}$ & 7 \\
\hline 100 & $\sqrt{ }$ & $\sqrt{ }$ & 3 \\
\hline 150 & $\sqrt{ }$ & $\sqrt{ }$ & 2 \\
\hline 200 & $\sqrt{ }$ & $\sqrt{ }$ & 2 \\
\hline 250 & $\sqrt{ }$ & $\sqrt{ }$ & 0 \\
\hline 300 & $\sqrt{ }$ & $\sqrt{ }$ & 0 \\
\hline 350 & $\sqrt{ }$ & $\mathrm{X}$ & 3 \\
\hline 400 & $\sqrt{ }$ & $\mathrm{X}$ & 5 \\
\hline 450 & $\mathrm{X}$ & $\mathrm{X}$ \\
\hline \multicolumn{3}{|l|}{$\sqrt{ }=$ terdeteksi sendi $\mathrm{X}=$ tidak terdefinisi } \\
\hline
\end{tabular}

Pada pengujian ini terlihat bahwa jarak ideal kamera terhadap user berada di jarak 250 $\mathrm{cm}$ karena pada jarak ini tidak terdapat error titik sendi. Untuk sistem ini menggunakan data skeletal tubuh bagian atas saja.

Pada penelitian ini mendapatkan hasil bahwa jarak ideal Kinect untuk mode tracking skeletal duduk dan dengan angkat tangan di peroleh pada rentang jarak 250-300 cm. jarak inilah yang menjadi acuan untuk penempatan kamera pada sistem terhadap user. Rentang jarak tersebut ditentukan karena tidak memiliki error pada jumlah titik sendi dari proses skeletal tracking.

Pengujian angkat tangan tercepat dilakukan untuk mengetahui pembicara yang paling cepat mengangkat tangannya. Sistem akan mengenali gerakan angkat tangan dari pembicara pada ruangan diskusi lalu menampilkan waktu angkat tangan tersebut dan menentukan yang tercepat. Pengujian ini dilakukan untuk melihat seberapa akuratnya sistem dalam menentukan pembicara yang tercepat mengangkat tangan. Cara menguji sistem ini dengan maksimal orang sebanyak tiga orang dan melakukan perbandingan jumlah orang dengan memberikan jeda waktu angkat tangan antara pembicara satu dengan yang lainnya. Jeda waktu yang di berikan bervariasi dimulai dari sangat lama hingga sangat dekat.

Pengujian ini dilakukan sebanyak seratus (100) kali pengujian dengan perbedaan waktu angkat tangan dari selisih waktu yg lama hingga sangat mendekati untuk perbedaan jumlah pembicara sebanyak dua orang dan tiga orang . pengujian ini dilakukan pada kedua metode deteksi angkat tangan yaitu deteksi menggunakan database AdaBoost dan deteksi menggunakan koordinat titik sendi. Dari hasil perngujian tersebut didapatkan hasil akurasi sistem dalam 
menentukan angkat tangan tercepat untuk dua orang pembicara dan tiga orang pembicara menggunakan dua metode yang berbeda. Sistem akan menentukan waktu tercepat dengan mencari waktu terkecil dari pembicara yang mengangkat tangan dan menampilkan waktu angkat tangan tercepat beserta id tercepat pada sebuah file. Pada pengujian terhadap dua pembicara menggunakan metode deteksi database AdaBoost ditemukan error penentuan angkat tangan tercepat sebanyak enam (6) data. Data tersebut mempunyai waktu yang hampir tetapi memiliki perbedaan beberapa millisecond saja. Pada pengujian angkat tangan tercepat terhadap tiga pembicara ditemukan error sebanyak tujuh (7) data. Pada metode deteksi angkat tangan dengan koordinat titik sendi ditemukan error data angkat tangan tercepat untuk dua orang sebanyak lima (5) data dan untuk tiga pembicara ditemukan error sebanyak lima (5) data. dari hasil tersebut dapat diketahui nilai akurasi untuk setiap metode dengan variasi jumlah orang. Pada Tabel 2 menunjukan akurasi penentuan angkat tangan tercepat.

Tabel 2 akurasi penentuan angkat tangan tercepat

\begin{tabular}{|c|c|c|}
\hline Metode Deteksi & Jumlah pembicara & Akurasi \\
\hline Database AdaBoost & 2 pembicara & $94 \%$ \\
\hline Database AdaBoost & 3 pembicara & $93 \%$ \\
\hline Koordinat Titik Sendi & 2 pembicara & $95 \%$ \\
\hline Koordinat Titik Sendi & 3 pembicara & $95 \%$ \\
\hline
\end{tabular}

Penelitian ini menggunakan deteksi gerakan angkat tangan untuk menampilkan waktu angkat tangan pembicara. Pada deteksi angkat tangan ini menggunakan dua metode berbeda yaitu metode database dengan menggunakan tools virtual gesture database Kinect dan metode deteksi angkat tangan menggunakan koordinat titik sendi pembicara.

Metode deteksi menggunakan database ini memanfaatkan tools yang sudah tersedia pada Kinect SDK v2.0. Database ini berbentuk diskrit dan menggunakan klasifikasi AdaBoost sebagai klasifikasinya. Pada tahap pembuatan database dilakukan dengan merekam data gerakan angkat tangan dan gerakan non-angkat tangan. Dari data tersebut dilakukan pemberian nilai jika angkat tangan maka bnernilai benar (true) sedangkan jika non-angkat tangan bernilai salah (false). Hasil database yang telah dibuat dalam sistem ini menggunakan tujuh video yang telah direkam dan dijadikan input dalam pembuatan database tersebut. Dari input tersebut didapatkan total data yang telah dilabeli salah dan benar sebanyak 55096 data. Data tersebut dilakukan training menggunakan klasifikasi AdaBoost sehingga didapatkan hasil akurasi sebesar 97.485497\%. Database ini hanya mendeteksi bagian upper body nya saja. Hasil database ini disimpan pada sebuah file bernama hand.gbd. file tersebut berisi data hasil training dari AdaBoost dalam bentuk binary. Tool VGB ini bersifat close source, sehingga dalam hal ini kita hanya menerima hasil jadi dari training yang dilakukan oleh system dalam VGB tersebut dan tidak mengetahui proses detail pada saat training databse tersebut. Waktu training yamg dilakukan pada VGB sampai menjadi sebuah databse adalah kurang lebih selama 6 jam. Waktu tersebut didapatkan pada komputer yang digunakan memiliki spesifikasi processor i7 dengan RAM 8GB. Waktu untuk melakukan training database dapat bervasiasi tergantung dengan spesifikasi komputer yang digunakan untuk melakukan training

Pada metode deteksi angkat tangan menggunakan koordinat titik sendi pembicara, dilakukan dengan cara memanfaatkan perbedaan letak koordinat antara titik sendi pergelangan tangan kanan dan kiri dengan titik sendi kepala terhadap sumbu Y. hal ini dapat dilakukan karena pada Kinect terdapat fitur coordinate mapper yang memungkinkan kita dapat mengetahui posisi titik sendi dari pembicara dalam satuan meter. Pada pengujian metode ini dilakukan 100 pengujian untuk deteksi angkat tangan pada pembicara yang berbeda-beda. Hal ini dilakukan agar dapat menentukan nilai akurasi dari metode deteksi angkat tangan menggunakan koordinat titik sendi. Pengujian yang dilakukan dengan menggunakan satu orang yang melakukan gerakan angkat tangan dan tidak angkat tangan. System mendeteksi angkat tangan dan akan menampilkan nilai benar (true) jika tidak mengangkat tangan system akan menampilkan nilai

Hand-Raise Detection Pada Kelas Cendekia Menggunakan... (Muhammad Fajar Khairul Auni) 
salah (false). Berdasarkan hasil pengujian yang dilakukan sebanyak 100 kali sistem mampu mendeteksi gerakan angkat tangan dengan jumlah error sebanyak 2 data. error ini dikarenakan pada saat pendeteksian posisi titik sendi terdakang tidak terbaca atau terhalang noise yang menyebabkan sistem tidak mendeteksi gerakan tersebut sebagai gerakan angkat tangan. Kelebihan sistem ini tidak perlu dilakukan training dan metode ini lebih ringan dalam hal komputasinya dibandingan dengan metode deteksi menggunakan database AdaBoost. Tabel 3 menunjukan perbandingan akurasi metode database AdaBoost dengan metode deteksi menggunakan koordinat titik sendi.

Tabel 3 Akurasi Deteksi Angkat Tangan

\begin{tabular}{|l|l|l|}
\hline No & Metode & Akurasi \\
\hline 1 & AdaBoost & $97.485497 \%$ \\
\hline 2 & Koordinat Titik Sendi & $98 \%$ \\
\hline
\end{tabular}

\section{KESIMPULAN}

Berdasarkan penelitian yang telah dilakukan dapat disimpulkan jarak ideal sensor Kinect terhadap pembicara berada pada rentang 250-300 $\mathrm{cm}$. akurasi yang dapat dilakukan sistem untuk menentukan angkat tangan tercepat menggunakan metode AdaBoost sebesar 93.5\% dan menggunakan metode koordinat titik sendi sebesar 95\%. Akurasi deteksi gerakan angkat tangan pembicara pada ruangan diskusi menggunakan metode AdaBoost diperoleh sebesar $97.485497 \%$ dan akurasi deteksi angkat tangan menggunakan metode koordinat titik sendi diperoleh sebesar $98 \%$.

\section{SARAN}

Pada penelitian ini terdapat beberapa hal yang perlu disempurnakan. Saran-saran yang dapat digunakan untuk menyempurnakan penelitian selanjutnya seperti perlunya face recognition untuk memberikan identitas kepada setiap skeleton yang terdeteksi untuk menyempurnakan pemberian identitas kepada pembicara. Kemudian diperlukannya Perlunya filter pada proses deteksi menggunakan koordinat titik sendi untuk menambah akurasi sistem.

\section{DAFTAR PUSTAKA}

[1] E. Oran, "Integrating Mobile and Ubiquitous Computing in a Smart Classroom to Increase Learning Effectiveness," Int. Conf. Educ. e-Learning Innov., pp. 1-5, 2012 [Online]. Available: http://ieeexplore.ieee.org/document/6360684/ [Accessed: 25-Feb2018].

[2] J. Park, K. An, D. Kim, and J. Choi, "Multiple human tracking using multiple kinects for an attendance check system of a smart class," 2013 10th Int. Conf. Ubiquitous Robot. Ambient Intell. URAI 2013, vol. 25, no. 10, p. 130, 2013 [Online]. Available: http://ieeexplore.ieee.org/document/6677494/ [Accessed: 25-Feb-2018].

[3] H. Hartono, L. Liliana, and R. Intan, "Pendeteksian Gerak Menggunakan Sensor Kinect for Windows," J. Infra, vol. 3, no. 2, p. pp-375, 2015 [Online]. Available: http://publication.petra.ac.id/index.php/teknik-informatika/article/view/3703/0 
[Accessed: 25-Feb-2018].

[4] T. Haryadi, U. Dian, N. Semarang, D. Graphic, U. K. Kali, S. View, S. R. Campaign, I. C. View, and T. Haryadi, "IMPLEMENTASI TEKNIK SABETAN MELALUI KINECT ( STUDI KASUS PENGENALAN GERAK WAYANG KULIT TOKOH ....," no. April, 2017 [Online]. Available: http://publikasi.dinus.ac.id/index.php/technoc/article/view/786 [Accessed: 25-Feb-2018].

[5] S. Dhali, "Vision based gesture recognition with Kinect sensor," pp. 1-21, 2015 [Online]. Available: https://www.overleaf.com/articles/vision-based-gesture-recognitionwith-kinect-sensor/zdyqxbggxfns.pdf [Accessed: 25-Feb-2018].

[6] W. Kurniawan and A. Harjoko, "Pengenalan Bahasa Isyarat dengan Metode Segmentasi Warna Kulit dan Center of Gravity," vol. 1, no. 2, pp. 67-78, 2011[Online]. Available: https://jurnal.ugm.ac.id/ijeis/article/view/1964/1769 [Accessed: 29-Feb-2018]

[7] M. Fuad, "Estimasi Jarak Menggunakan Sensor Kinect," J. Ilm. Miktrotek, vol. 1, no. 1, pp. 5-10, 2013 [Online]. Available: http://journal.trunojoyo.ac.id/jim/article/view/151/151 [Accessed: 25-Feb-2018].

[8] M. Fuad, F. Teknik, U. Trunojoyo, R. Telang, and P. O. Box, "Pengenalan Gestur Semaphore Menggunakan Sensor Kinect,” pp. 266-270, 2014 [Online]. Available: https://informatika.uc.ac.id/wp-content/uploads/2017/11/snapti-2015/(266-

270)\%20Muhammad\%20Fuad\%20-

$\% 20$ Pengenalan\%20Gestur\%20Semaphore\%20Menggunakan\%20Sensor\%20Kinect.pdf [Accessed: 25-Feb-2018].

[9] I. Surya, A. Permana, I. Wijayanto, and E. Susatio, "DETEKSI PENYUSUP BERDASARKAN ANALISIS DEPTH FRAME MENGGUNAKAN KAMERA KINECT INTRUDER DETECTION BASED ON DEPTH FRAME ANALYSIS USING KINECT CAMERA Keterangan: I C ( i ) I B ( i ) = intensitas frame pada pixel ( i ) = intensitas background pada pixel ( i )," vol. 3, no. 3, pp. 4765-4772, 2016 [Online]. Available: https://repository.telkomuniversity.ac.id/pustaka/121449/deteksi-penyusupberdasarkan-analisis-depth-frame-menggunakan-kamera-kinect.html [Accessed: 25-Feb2018].

[10] I. Wijayanto and E. Susatio, "IDENTIFIKASI PERGERAKAN DASAR PADA GAME UNTUK PENGEMBANGAN GESTURE RECOGNITION BERBASIS KINECT Identification of Basic Movement on The Game for A Gesture Recognition Based on Kinect," vol. 4, no. 2, pp. 1988-1995, 2017 [Online]. Available: http://repository.telkomuniversity.ac.id/pustaka/135849/identifikasi-pergerakan-dasarpada-game-untuk-pengembangan-gesture-recognition-berbasis-kinect.html [Accessed: 25-Feb-2018].

[11] R. E. Schapire, "Explaining adaboost," Empir. Inference Festschrift Honor Vladimir N. Vapnik, pp. 37-52, 2013 [Online]. Available: http://rob.schapire.net/papers/explainingadaboost.pdf [Accessed: 25-Feb-2017]. 
[12] A. A. Hassan and S. N. Basah, "GESTURE-BASED REMOTE-CONTROL SYSTEM USING COORDINATE FEATURES Abdirizak Abdullahi Hassan and Shafriza Nisha Basah," vol. 11, no. 8, pp. 4979-4986, 2016 [online]. Available: https://pdfs.semanticscholar.org/0ed5/7772ea3472cb2501c9b65421ee3370ccb137.pdf [Accessed: 25-Feb-2017]. 